luteous, the veins and the middle of the cells more or less infuscated and the outer margins of the dorsal field black between the veins; wings very long. Legs luteous, the hind femora dotted with fuscous exteriorly. Ovipositor somewhat longer than the hind femora, straight, the apical blades long and tapering, scarcely enlarged basally, unarmed. Length of body, $125 \mathrm{~mm}$. ; of hind femora, $8.25 \mathrm{~mm}$.; of ovipositor, $9 \mathrm{~mm}$.

I $q$, Colorado in New Mexico, T. D. A. Cockerell, B. 59 .

N. melleus sp. nov. Dull luteous. Head feebly infuscated above, clothed with sparse black bristles, and with three short longitudinal fuscous stripes posteriorly; eyes rather prominent; antennae luteous, feebly infuscated; maxillary palpi luteous, the last joint infuscated only at extreme transversely truncate tip. Pronotum very sparsely beset with black bristles, transverse, tapering rapidly, posteriorly fully twice as broad as long, the incisures fuscous, two small, transverse, oval, fuscous spots in the middle of either side of the disk posteriorly. Tegmina nearly as long as the abdomen, luteous, but infumated basally along the inner margin; wings more than twice as long as the tegmina. Legs luteous, the hind femora feebly and obscurely infuscated. Cerci slender, reaching to beyond the middle of the ovipositor. Ovipositor straight, a little longer than the tegmina and a little shorter than the hind femora, castaneous, the apical blades black, slightly enlarged basally, beyond tapering regularly to a fine point, the teeth exceptionally minute and crowded. Length of body, II.5 mm.; of hind femora, $8 \mathrm{~mm}$.; of ovipositor, 7.1 $\mathrm{mm}$.

I + , San Rafael, Vera Cruz, Mexico, Townsend (L. Bruner).

\title{
NOTES ON THE WINTER INSECT FAUNA OF VIGO COUNTY, INDIANA.- VII.
}

BY W. S. BLATCHLEY, INDIANAPOLIS, INDIANA.

\section{COLEOPTERA (Cont.).}

\section{Elateridae.}

Fifty-three species of this family are known to occur in the county. Representatives of but twelve of these have been taken during the winter months, as follows :

184, Adelocera discoidea Web. On several occasions in winter beneath loose bark of logs. An uncommon species.

185 , Lacon rectangularis Say. Occurs only on a dry sandy hillside where the river terrace meets the old canal.
There it is frequent beneath chips and chunks. Dec. I2. Jan. I.

I86, Cryptohypnus pectoralis Say. One specimen only from the county. Jan. 7, beneath chunk.

I87, C. obliquatulus Melsh. Frequent in winter beneath logs on sandy hillsides.

I88, Monocepedius auritus Hbst. Very common in winter beneath logs and mullein leaves on sandy hillsides. Varies from reddish-brown with black markings to deep black, three distinct color forms occurring. Usually two or three hibernate together. 
I89, M. bellus Say. Frequent throughout the winter. Beneath chunks in damper localities than the preceding.

190, Elater sanguinipennis Say. A handsome but uncommon elaterid. Taken but once in winter, Feb. 2, from beneath a $\log$ in the sandy bed of the old canal.

I9I, Dolopius lateralis Esch. Dec. 23 and Jan. 5, from beneath logs on sandy hillside. Scarce.

192, Melanotus fissilis Say.

I93, M. communis Gyll. Both are among the most common of winter beetles. Usually two to six together beneath loose bark, logs, mullein leaves, etc. In common with most elaterids they feign death when disturbed.

194, Corymbites rotundicollis Say. A single specimen, taken Dec. I 2 , from beneath a $\log$, on the sandy hillside mentioned under No. 185 above, represents the species in my collection.

195, Asaphes memnonius Hbst. Scarce. Winters beneath the bark of red oak logs.

\section{Throscidae.}

196, Throscus chevrolati Bonv. One only, Jan. 21, from beneath a rail on the side of the old canal.

\section{Ptinidae.}

197, Endecatomus rugosus Rand. Several at intervals in winter in woody fungi and beneath logs.

\section{Cioidae.}

198, Cis fuscipes Mellie. One, Jan. 7, from beneath a chunk near the border of a swamp.
LUCANIDAE.

199, Dorcus parallelus Say. A single specimen, Dec. 8 , from beneath a partly burned log. Most common in June.

200, Passalus cornutus Fab. Abundant throughout the winter in its usual abiding places - the juicy depths of half decayed logs.

\section{Scarabaeidae.}

This family is represented in the county by ninty-eight known species. Of these, but ten have been found in the imago stage in winter.

201, Choeridium histeroides Web. Winters sparingly in dry cow-dung and beneath logs.

202, Copris minutus Drury. Once in winter. Feb. 28th, beneath chunk in upland open woods.

203, Ataenius cognatus Lec.

204, Aphodius fimetarius Linn.

205, A. inquinatus Hbst.

206, A. terminalis Say. Of these, cognatus, fimetarius and inquinatus winter in large numbers in dry cowdung and in the earth beneath it; also beneath logs on sandy banks. On warm sunny days, even in midwinter, they may be taken on the wing and they fly by thousands in early spring. A. terminalis has similar habits but is much less common. Three additional species of Ataenius and seven of Aphodius have been taken in the county and most, if not all, of them doubtless hibernate as imagoes; several having been taken in March but not in the winter months. 
207, Geotrupes splendidus Fab. This very common beetle has been seen on the wing on numerous occasions in March, and a pair was found in copulation beneath a log on Dec. 2oth. They usually mate in May.

208, Trox aequalis Say. The only one of the nine species known to occur in the county which has been found in winter. Once, Dec. I 2 , beneath rail in fence corner.

209, Valgus canaliculatus Fab.

210, $V$. squamiger Beauv. Both have been taken on several occasions in winter, notably on Dec. ro, I893, when they were found gregarious in numbers beneath a half hollow decaying chunk which was filled with dry dirt and situated in an upland thicket. A single specimen of canaliculatus taken at that time is unique in having the tergite of the terminal ring of the abdomen prolonged into a sharp spine, $3 \mathrm{~mm}$. in length. Mr. H. F. Wickham mentions in a private letter the finding of an example of the same species in Michigan, which possesses a similar abdominal projection.

\section{Chrysomelidae.}

One hundred and nine species of this family have been collected in the county. Of these, mature specimens of but twenty-six have been taken in the winter months.

2I I, Myochrous denticollis Say. Represented in my collection by a single specimen, taken Feb. 28, from beneath a chunk in the river terrace woods.
2I2, Metachroma angustula Cr. Once in winter, Feb. $\mathrm{r}_{4}$, from between mullein leaves. Common in June on the flowers of Cornus and Ceanothus.

213, Doryphora clivicollis Kirby. Uncommon at any time. Once, Jan. 5 , from beneath mullein leaves. Several times, single specimens in March. On milkweed flowers in June.

2I4, D. ro-lineata Say. Much less common than 20 years ago. Usually hibernates in the ground at a depth of I 8 to 20 inches, but sometimes beneath logs, rubbish, etc. On the wing in early spring.

215, Chrysomela suturalis Fab. Dec. Iо.

216, C. similis Rog. Feb. 2 1.

217, C. praecelsis Rog. These three winter sparingly beneath chunks near the borders of sandy cultivated fields and along the old canal. Suturalis is rare, the others frequent. Three additional species, elegans Oliv., multipunctatus and auripennis Say, have been taken in the county, the first and last on dates (Mar. I4 and Nov. 21) which lead me to infer that they also hibernate as imagoes.

218, Cerotoma caminea Fab. Rare. Three only from county. One, Feb. $2 \mathrm{I}$, beneath $\log$ in lowland woods.

219, Diabrotica vittata Fab. On numerous occasions in winter from beneath logs and rubbish in dry sandy places, especially along the borders of fields in which melons and cucumbers had been cultivated.

220, Galeruca notulata Fab. Be- 
neath chunks and mullein leaves. Dec. Io, Jan. 16.

221, Hypolampsis pilosa Ill. One only, from beneath a chunk in the bed of canal. Jan. I.

222, Oedionychis gibbitarsis Say. 223, O. vians Ill.

224, O. indigoptera Lec.

The above are the winter representatives of the six species of the genus found in the county. Gibbitarsus and vians were taken on numerous occasions ; indigoptera, once, Feb. I4, all from beneath logs and rubbish.

225, Disonycha discoidea Fab.

226, D. collaris Fab.

227, D. collata Fab.

228, D. cervicalis Lec. These four frequent throughout the winter beneath mullein leaves and rubbish. Four additional species of the genus occur in the county.

229, Haltica chalybea Ill. One of the two specimens taken, was found Dec. Ioth beneath the bark of an oak log.

23o, Systena frontalis Fab. Once in winter, Feb. I4, from beneath the bark of the White Maple (Acer dasaycarpum Ehrh.) Common in June on the leaves of the great ragweed ( $\mathrm{Am}$ brosia trifida L.).

23I, Longitarsus turbatus Horn. Feb. Io, from beneath logs. Frequent in June on the leaves and stems of the false gromwell, Onosmodium carolinianum D. C.

232, Chaetocnema denticulata Ill. Frequent beneath chunks in fence corners filled with dead leaves, Jan. 6 .

233, Odontota dorsalis Thunb. But once in winter, Dec. 25, from beneath the bark of a locust (Robinia pseudacacia L.) log. Frequent in summer.

234, Cassida bivittata Say.

235, C. thoracica Ill. Dec. 29.

236, Coptocycla guttata Oliv.

Of these bivittata and guttata are frequent in winter; the other rare at any season and once on date given. All hibernate beneath chunks and chips in damp localities.

\title{
SOME ADDITIONAL SPECIES OF PROSAPIS.
}

\author{
BY T. D. A. COCKERELL, MESILLA, N. MEX.
}

Prosapis labiatifrons, n. sp., ठ.- Length, $5 \frac{1}{2} \mathrm{~mm}$., black with orange markings. Head fairly large, face only moderately narrowed below; clypeus, supraclypeal mark and lateral marks dull orange-yellow with a slightly buff tint. Supraclypeal mark quite broad, elongated, extending up between antennae. Lateral marks strongly excavated by antennal sockets on inner side, at the same level strongly curving inwards, reced- ing from the orbital margin; the lateral marks as a whole strongly recall the corolla of a labiate flower, whence the specific name. Scape orange in front, hardly dilated at all. Flagellum dark brown, reaching a little beyond tegulae. Vertex and front strongly punctured, the punctures on front not running into grooves. Mesothorax, scutellum and pleura strongly punctured, the punctures on hind part of mesothorax conspicuously 

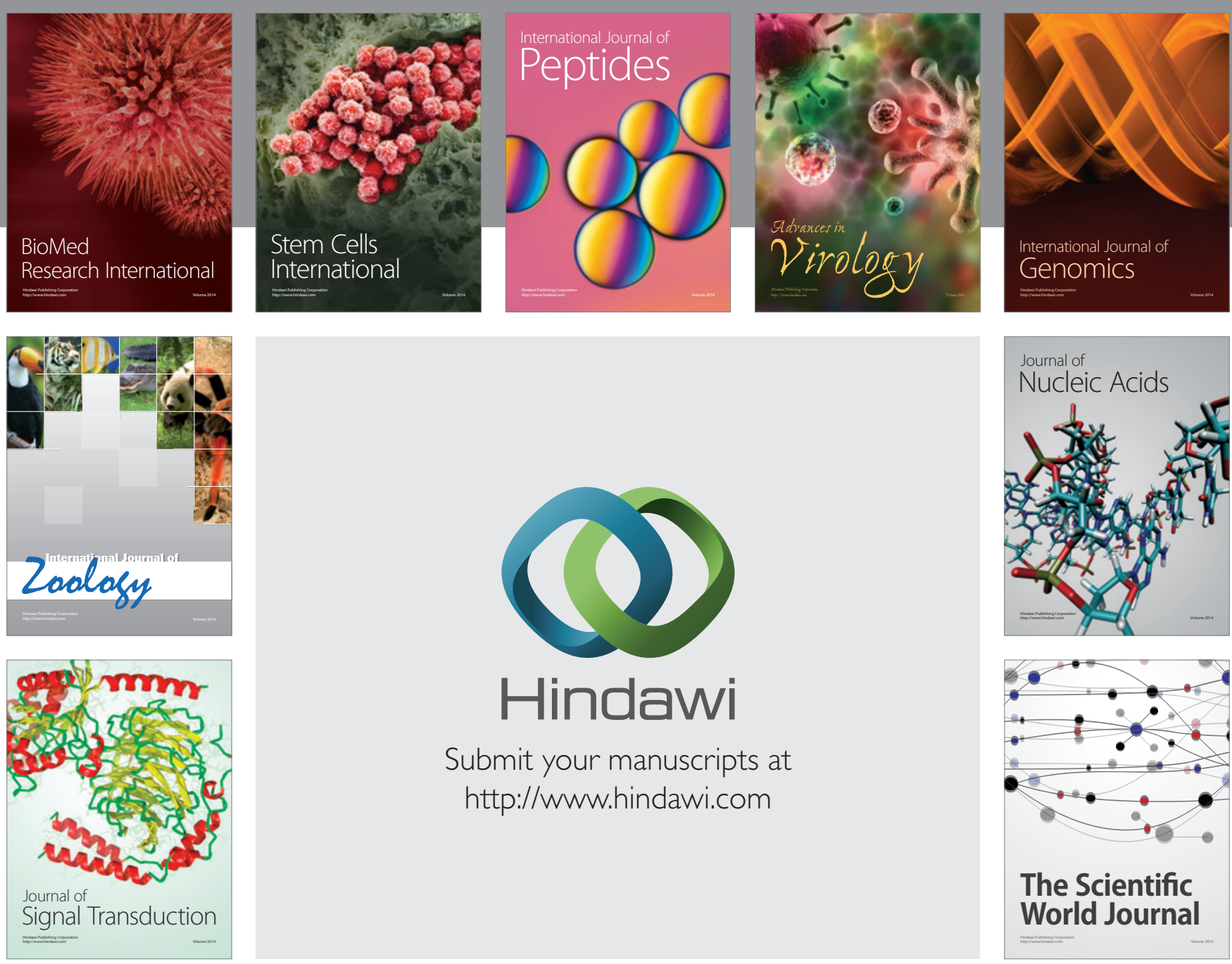

Submit your manuscripts at

http://www.hindawi.com
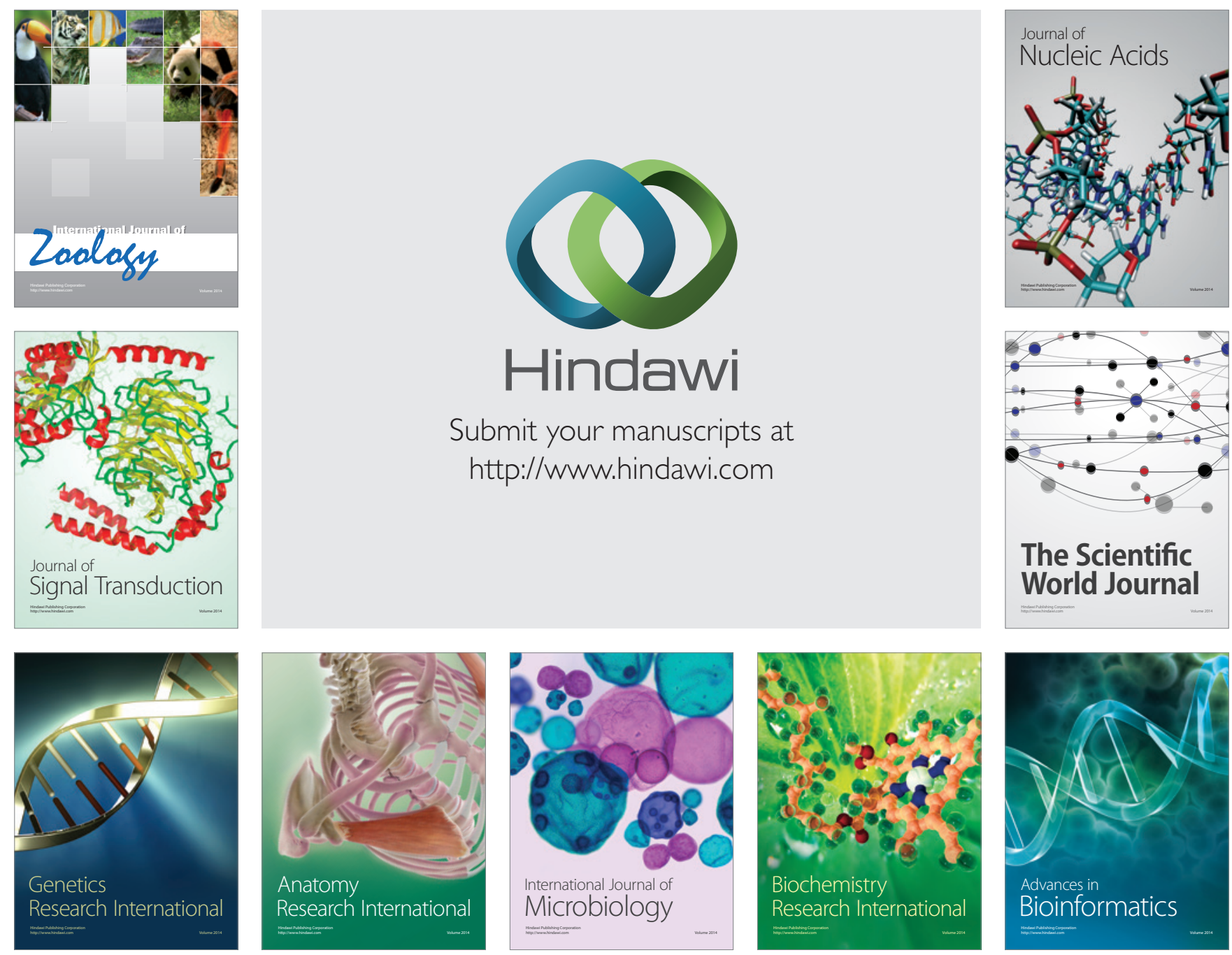

The Scientific World Journal
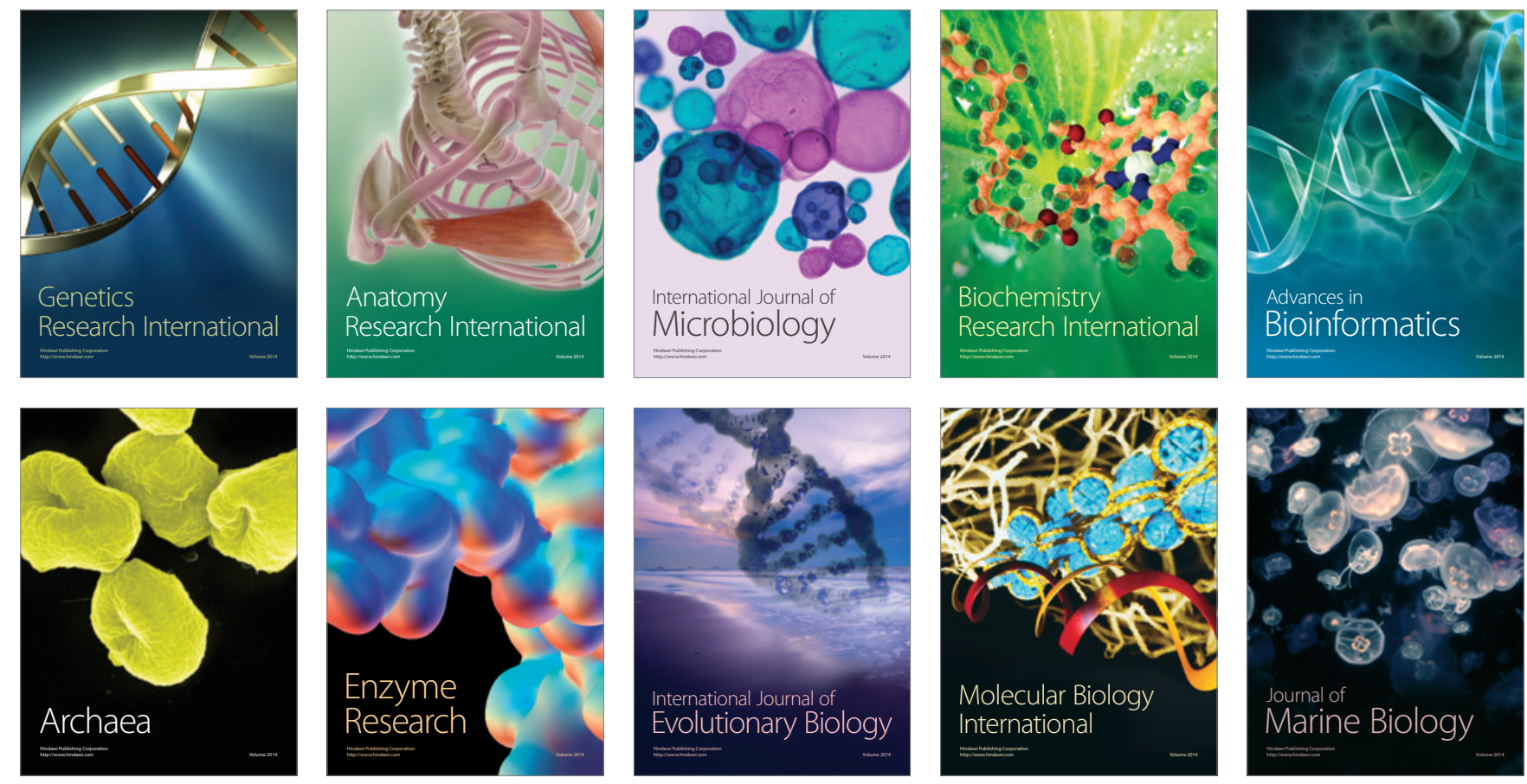